\title{
Factors That Would Argue in Favour and Against the Introduction of HRM in the Public Sector: A Retrospective Study
}

\author{
HASSAN ELSAN MANSARAY \\ Department of Business Administration and Entrepreneurship Development, \\ Institute of Public Administration and Management (IPAM) University of Sierra Leone, \\ Freetown, Sierra Leone \\ E-mail: hassanelsan@gmail.com
}

Received: Oct. 20, 2019 Accepted: Nov. 19, 2019 Online published: Nov. 22, 2019

doi:10.5296/ijhrs.v9i4.15881 URL: https://doi.org/10.5296/ijhrs.v9i4.15881

\begin{abstract}
This study critically discusses the argument for and against the establishment of HRM in the public sector and the challenges faced in terms of staff motivation, cultural change of tenure of office of public servants and downsizing of staff. The study found that the development was slanted by a variety of reasons, comprising amplified competitive pressures triggered by deregulation and globalization, and the inspiration of distinguished scholars in the US and the UK. The aim is to provide chances for a new type of analysis call the new industrial relations. Which is alternative means of individualizing industrial relations - management will now focus more attention on individual employees than collectively. The introduction of HRM in the public sector was as a desire for governments to provide increase quality public services. In this vein, the need for efficient public sector organizations emerged. Moreover, reactions all over the world have centered on pinpointing the main business of government was to exposed the public sector to rivalry; and subcontracting aspect of service provision and support functions. The failure of old-fashioned controls had created customer/user choice. It was on these communities' expectations that governments are becoming facilitator instead of straight provider of public services. However, the costs of accepting HRM practices and values were contended to have intended to expurgate employees' benefits and wages. Also brought changes on the culture and structure in the public service accompanied by cutting back staff.
\end{abstract}

Keywords: HRM, public sector, government, Sub-Sahara Africa (SSA), civil service, public service, public servants, civil servants 


\section{Introduction}

The mid-eighties saw two significant developments in many advanced industrialized economies. These developments are the decline of union density, recognition and collective bargaining. Also the emergence of theory of human resource management, which became the popular language of many management practitioners around the globe. However, the old-style notion of personnel management came into practice by industries after the World War I. This era was mainly concerned about the basic necessities of employees. This period, (from the 1940s to the 1970s) saw the growth and advanced stages of personnel management, mostly in relation to industrial relations issues (Armstrong, 1997 and Gunnigle et al, 1997). The term HRM originated from the United States of America in the 1950's but gained wide recognition in the 1980's as a modern way of managing people. This development was caused by a variety of reasons such as the augmented competitive pressures triggered by deregulation and globalization, as well as the inspiration of distinguished scholars in the US and the UK. Moreover, the change was triggered by the call from citizens along with tax payers in the industrialized countries for better-quality public services (Engida and Bardill 2013). The aim is to deal with a collection of personnel management matters. A few scholars believe that, it provides chances for a new type of analysis they call the new industrial relations. Which is an alternative means of individualizing industrial relations. Thus, management will focus more attention on individual employees than collectivity (Beaumont 1995).

In Armstrong (2009), Lawton and Rose (1994), Legge (1995) and Gunnigle and Flood (1990) there is a suggestion that HRM may be no more than a 'set of initials or an old wine in a new bottle' or an 'old style personnel management with a new name'. However, Storey (1989) finds four patterns of HRM which differentiate it from the traditional personnel management viz:

- it is openly related to corporate strategy;

- it search to gain commitment from employees instead of their compliance;

- employee commitment is achieved through a combined approach to human resource policies such as, reward, appraisal, selection, training also;

- HRM promotes integration through line managers.

Nevertheless, there is slight concord on the theoretical connotation of HRM. Many different definitions have emerged on the subject area, as there are numerous researchers. During the early period of HRM it was recommended by Armstrong (1987 cited in Armstrong 2009:13) that:

HRM is regarded by some personnel managers as just a set of initials or old wine in new bottles. It could indeed be no more and no less than another name for personnel management, but as usually perceived, at least it has the virtue of emphasizing the virtue of treating people as a key resource, the management of which is the direct concern of top management as part of the strategic planning processes of the enterprise. Although there is nothing new in the idea, insufficient attention has been paid to it in many organizations.

Recent definition of HRM was defined by Daly (2015) as a practice that involves devoted 
professionals working supportively with other talented organizational and community members to achieve the organization's vision, mission, goals, and values. As such, HR management operates as a service unit for other operational units. HR attempts to develop policies, plans, programs, and initiatives that progress other working units' human capacity and their capability to deliver high-quality products and services to customers, clients, or citizens (in the case of government).

On the other hand, critics such as Guest (1987) and Storey (1995) perceive HRM as a considerably dissimilar ideal constructed on unitarism (that employees should have similar interests such as employers), individualism, high commitment and strategic alignment (i.e. incorporating HR strategy with business strategy). It was also discovered that HRM is more comprehensive than old-fashioned personnel management. Besides, HRM has highlighted the view that people should be viewed as assets rather than variable costs.

Nevertheless, Human Resource Management has come to be an accustomed term in the public sector organizations, even though it sometimes produces mixed responses from critics. As, it is perceived as the modern brand for procedure driven personnel management actions such as, managing pay and state of affairs, with slight contribution to the planned management of the business (Premier and cabinet 2001).

Public sector is however, defined by the investorword.com as a portion of the economy that is concern to provide elementary government services. However, the configuration of the public sector differs by countries. Nonetheless, most countries public sector comprises such services like: the police, military, public roads, public transit, primary education and healthcare for the poor. Also, the public sector could offer services that non-payer cannot be exempted from using them such as, street lighting, services which benefit all of society rather than just the individual who uses the service like public education, and services that inspire equal opportunity. However, not all public sector organizations have the ability to provide some of these services to the public, because of financial constraints.

\section{Literature Review}

\subsection{Factors in Favour of the Introduction of HRM in the Public Sector}

As the desire for government to provide quality public services upsurges, the need for wellorganized public sector organizations materialized. Moreover, reactions all over the world have centered on pinpointing the main business of government was to exposed the public sector to rivalry; and contracting out aspect of service supply and support roles.. This interruption of traditional controls has begun to generate customer/user excellent. It was on these publics' expectations that governments are becoming facilitator instead of straight provider of public services. (Premier and Cabinet 2001).

Moreover, the commencement of New Public Management with a stress on transmitting private sector management approaches into the public sector, relocated the emphasis on the public sector to act like an organization instead of management. Besides, it was one general strategy to attain proficiency that will lead to quality service (Brown 2004, United Nations, 2005). This apprehension has been earlier expressed by Stewart and Walsh (1992) that the 
public service has to transform the way it is carrying out its functions, in order to maintain its legality that will mirror the concepts about what makes a good management. And, this transformation has to be characteristically established on private sector philosophies.

This was part of a wide tactic to get an upright organization that can create achievement through the provision of value service to the public. Furthermore, modifications in the public sector were propelled in reply to the thought necessity to reduce government expenditures in order to offer more well-organized public goods and services. The challenge was the need for new skills, approaches and behaviours among public officials at all levels to react efficiently to the increasing intricacy as well as the number of demands to be found on governments. It was not astounding at that time that the main capabilities for the public sector of the 21 st century vary in numerous ways from the past (United Nations, 2005).

It is through the civil service reforms (later known as the public service reforms) that several African countries such as Tanzania, Ghana, Kenya, Zambia, Sierra Leone just to reference a few, noticed a momentous decline in the proportions of their civil service units. The acceptance of public service transformations has been successful to the working of formalities in the developed as well as developing countries in many venerations. For example, the reform has encouraged the instillation of the meritocracy ethos in the public service in capacities like recruitment and selection, promotion, record keeping, performance appraisal and employees' benefit. It was an enormous stride to remodel the public service around the globe. The move marshaled abundant successes ever since the adoption of HRM in the public service (Mutahaba 2007 and 2013)

Interestingly, this view had gained momentum in the public sector in Australia, Britain and SSA countries especially South Africa, Sierra Leone and other foreign countries, that HRM can support a new and unique approach to managing people. In addition, because of the increasing business demands faced by organizations, a strategic approach to HRM has to emerge in order to meet with those demands. This tougher brink to HRM is today promoting chief executive officers, managers and HR professionals to reconsider their traditional view of their calling (Premier and Cabinet 2001)

The introduction of new classification structure and work arrangements in the 1990s in Australia has changed the public sector employment relations. This new classification structure and work arrangement has reinforced public sector commitments to merit, equity and a career service (Smith 1994). Although, the changes do fragment and alter the structures and processes which, were based on a single public career service. However, the reform made it possible to achieve competence and output in the public service. The changes likewise, minimize repetition strain injury and other occupational health and safety risks. It also eliminate too much bureaucracy in dealing with matters of urgency, and reduce over spending. For example a governmental concern for effective service delivery, read as 'getting on with the job', may foster... impatience with procedural obligation. Or a concern with economic management, read as 'minimizing resource usage, may cut across personnel equity consideration' (Alford 1993:6).

In the 1980s and 1990s, the conservative governments in Britain have been urging public sector 
managers to imitate the efficiency of the private sector. It means, they have to replace the traditional approaches and practices of public management to that of the private sector. Thus, the UK public sector should be compelled by the demands of those foremost public organizations for real job performance, extraordinary quality of productivity, better service to customers and worth for money (Farnham and Horton 1996). A lot of reforms required by the conservative governments in the 1980s and 1990s were determined to modify the cultures of the public services, which were led by the old-fashioned ways of management that were based on chain of command and experience. The move was a challenge to trade unions and their allied, who saw themselves as protectors of the existing state of affairs (Stewart and Walsh 1992).

In February 1988, the British government published the next steps programme in order to reform the civil service and improve the public management. The Ibbs report or the next steps required the government department and its agencies to market-test their activities. The aim of this practice was to increase efficiency and improve services rendered by the public service. The next steps programme created three large agencies with several sub-groups. These agencies are not only to cope with the massive operational functions that were formally under the direct responsibility of Whitehall but; in the drive for efficiency and savings, have made quite considerable changes in the way staff employment in the positions of the civil service are spread (Pilkington 1999).

The next steps programme detached the operation of the agencies and their chief executive from being accountable to parliament, or the electorate, like the way government ministers and their department used to do. Nevertheless, the chief executive will be informing the committee on how his agency has been carrying out its responsibilities. This new method has improved the system of transparency and accountability in the public service. However, the Ibbs report has really transformed the civil service from the 'deadweight bureaucracy' which, Margaret thatcher was so distrusted. As Pilkington (1999) commented, the next steps programme and the allocation of civil service undertakings to a network of agencies actually change the nature, structure and even the role of the service.

However, Public sector restructurings in Africa were compelled by economic reform, democratization and the exploration for managerial competence as a way of stimulating the provision of quality goods and services to the public (ECA (2010). Many, Sub-Saharan African countries have embarked on reforming their public services since the 2000s. When they realized that there are excess staffs with low output. Hence, saw the need to resuscitate the merit system. This gap was because of policy makers' failure to respond to the far-reaching changing economic situation in those countries. Where, there are sharp decline which has led to fall in revenues, while expenditures continue to rise. As a result, it became difficult to meet with the payment of regular salaries to their civil service personnel. However, some countries right-sized their civil service instead of downsizing. This was done as a result of promoting efficiency in the Public sectors of those countries. Although, the approach incorporated the laying off of some workers; but also recruited staff with needed skills. Nevertheless, the African knowledge of relating merit in the public service has similarly understood the important of complementary merit with other thoughts meant at safeguarding some gradation 
of representatives- such as, race (in South African), ethnic groups (e.g. in Nigeria and Ethiopia) and lately gender (e.g. in Chad and South Africa) (Adamolekun 1999, Olowu 1999)

Another positive step in the public service restructuring in the SSA countries is on the financial management budget transformation and expenditure controls which help to guarantee an additional calculated method to resource distribution and management (Adamolekun and Kiragu 1999).

In the model of the new public administration, Minogue (1998), identified four drastic modifications on the prevailing practices as vibrant:

1. Restructuring the public sector, mainly through privatization;

2. Remodeling and reducing central civil services;

3. Outsourcing public services to the private sector thereby making internal markets for rivalry and improved service provision;

4. Improving competence, particularly through performance auditing and measurement.

Moreover, it is held that a great level of contribution and participation of the citizens is favorable to viable development. It is important to note the principles of the new public management, (such as decentralization, privatization, subcontracting along with partnerships with civil society) which comprise non- governmental organization (NGOs) give significant inter-organizational ways for amassing involvement, at the same time making sure there is additional operational and efficient public service delivery (ECA 2003 in Engida and Bardill 2013).

Moreover, the introductions of HRM in the SSA public sectors make it possible for these sectors to embark on manpower planning in order to have sufficient human resources that will meet their temporary and long standing necessities. In addition, staff development is followed to promote training and education that will be necessary to develop the overall career of each staff. These strategies were aimed at decreasing the enormousness of the cost of public service in order to make them more receptive to customers and clients. At the same time, style them into well-organized organizations modeled along the private sector ranks. (Adamolekun 1999, Olowu 1999).

The post-1994 Public Service in South Africa was faced with huge tests equal in terms of its own reform, and the change of its services offered to the people. Because of these challenges a White Paper on Human Resource Management in the public service was developed to address these challenges through an all-inclusive programme of policy inventiveness, supported by liberal legislative modifications. The creativities was to attain a major managerial move from a centrally controlled process-driven Public Service, to a service that is representative of all South Africans that will delight all public servants as valued resource. The change could be abridged as a change from personnel administration to human resource management, which the White Paper sturdily supports. 
Also, the reason for the White Paper was to deliver a policy agenda that will facilitate the development of human resource management practices that will upkeep an operative and proficient Public Service that will gear towards economic and social change. The Human resource management as a result, was regarded as one of the deliberate tools of the alteration framework for the Public Service in South Africa (South Africa "White Paper" 1995)

Besides, the shift from personnel management to Human Resource Management in Sierra Leone Civil Service developed after the devastating civil war, and the subsequent restoration of peace in the country in 2002. The Government through the support of international donors and UK Department for International Development (Dfid) embarked on a range of public service reforms. To pursue the reforms, a Steering Committee on Good Governance was set up to guide and oversee reforms through funds provided by the UK Department for International Development (Dfid). The mandate was to review the structure and functions of all Government Ministries and to improve human resource management and records management in the civil service. However, HRM is a relatively new approach in managing people in the Civil Service of Sierra Leone. Following the transformation of the Establishment Secretary Office's to the Human Resource Management Office on the 7th August, 2008, the goal of Human Resource Management Office was to maximize the productivity of the civil service by boosting the efficiency of its employees. While simultaneously to improve the work life of employees and treat them as valued assets. The development of Human Resource Management Office in the civil service saw the shift from personnel administration to a more strategic management that has transformed complicated views to ones that are more natural, interactive and cooperative. As a result, the civil service structures are now viewed as necessarily more flexible and workable (Annual Report 2014).

Gardner (1993); Gardner and Palmer (1997) and; Shim (2001) pointed out that the flexible nature of the Public sector has been branded through the formation of more malleable structures and processes. With superior accountability given to line managers and supervisors in the management of employees through flatter management structures as well as programmes of decentralization and devolution. On the job level, wider and multi-skilled jobs were hosted. Moreover, there was more focus on performance and productivity measures.

Thus, the new prototypes of HRM in the public sector have presented the human resources with the notion of having the ability to accomplish performance consequences in agreement with the planned direction of the public sector organization (Gardner and Palmer 1997). Based on this bearings, there is a stress on fortifying and maintaining public servants who could attain anticipated results. Consequent upon this orientation, a pull to pieces of internal labour market as well as lesser or no commitment in upholding job security has become the focus on operations of the organization. Therefore, human resource system now depend on performance management for workforce flexibility and productivity.

As a result further, the varying scopes of public sector employment label HRM to have formulated a key influence on the operation of the public sector. The support of human resource management in comprehending the 'new' public sector is however noteworthy. Therefore, the New Public Management is position on the centre phase for moving the agenda 
for change. By introducing multiskilling, reorganized career paths as well as eliminating seniority as a base for promotion. Also, by placing more importance on equity contemplations and the removal of inflexible employment classifications which have been more or less the paybacks of moving from personnel administration to HRM in the public sector (Brown 1997, Brown 2004). At this interval, I now shift my arguments that centre to against the introduction of HRM in the public sector.

\subsection{Factors Against the Introduction of HRM in the Public Sector}

Several criticisms have been necessitated on the attempt in toning public management to private management. Stewart and Walsh (1992) argued that, in accepting a private sector language in the public sector there will be risk that organizations in the public realm may abandonment the morals that are intrinsic in that field. They further mentioned that more emphasis was placed on the British civil service to have a commercial culture that should bring about a business approach. But, forewarned the endangerment if, this approach may perhaps lead to the negligence of the tenets of the public dominion.

This argument has been pursued by various critiques in the sense that the new HRM practice has wiped out or demised the old HRM practices such as, the authoritarian panache of management, which pretend to defend and support the happiness of the labour force. Nevertheless, this type of management was concerned on the health, safety and welfare of employees, as well as their output. In addition, there were strong trade unions within the public sectors; with effective bargaining power in areas like, wages and better conditions of service. Besides, workers' participation and consultation was excessive. Critiques further observed that, in the past, public organizations were considered to be model employers who fixed criteria for private organizations to copy. But, the HRM practices in the public sectors nowadays have weakened these traditional features through government policies, since 1979 (Boyne, Glenville and Michael 1999, Boyne et al 2002).

The new system however, has been criticized further, for the subsequent destruction of employment conditions and prospects for career development. It has also resulted to far-reaching downscaling and outsourcing which has debatably added to inferior quality of service delivery. Moreover, the key vicissitudes and transformations of the public sector has led to the weakening of some of the does and state of affairs that have conventionally tell apart the public sector from other organizations in the private and non-profit sectors. Equally, the penalties of accepting HRM practices and values were contended to have intended to expurgate employees' benefits and wages and brought changes on the culture and structure in the public service as well as cutting back staff. (Black and Upchurch 1999).

It is similarly clear that the reforms have compelled changes on how the public sector interrelates and nurture relationships with outside organizations. Similarly, subcontracting and competitive offering have brought new prototypes of market-based service delivery (Klijn 2002). In view of that, the shifting nature of how government provide services has changed the way the relationships between the public sector and other sectors should exist, especially the community sector. There is now more rivalry between service delivery organizations on outsourcing. This has overstretched community sector organizations to answer back to wider 
kinds of service delivery under circumstances of competitive proffering or through predetermined engagements that will stipulate more thoroughly the way the human resources are positioned to convey services. This situation has warranted more anticipations on the side of government funding bodies with regard to community organizations in making sure that they have well-structured organizations with abundant skilled human resources to deliver the needed services (Brown and Ryan 2003).

As pointed out by Mutahaba (2013) that the African public service systems is still facing major challenges which has reduced the effectiveness and output of the civil service. One of the main experiment is connected to the improvement of professionalization in handling human resources. Because, there is mounting agreement amid managers, academics and human resource practitioners all over that human resources are the crucial and prospective resource for actual delivery of public services along with the application of development creativities such as national visions and poverty reduction plans. In spite of the essential part human resources perform regarding the upgrading of better-quality public services delivery; evidences from public services in many African countries have proposed that there is incomplete use of expertise in managing human resources.

Another argument is that, the public service no longer offer job for life guarantee. Because it has replaced the uniform and standardized employment practices to that of flexibility and differentiation. This new practice favours part-time or temporary contract as a way to discourage the 'job for life' guarantees system. Moreover, it has been observed that the new HRM focuses on individualism instead of collectivism in dealing with employees and their issues, especially managerial staff. This strategy was used by the next steps agencies to reduce the role of trade union on negotiating on employment conditions. Additionally, the conservative government introduced the next steps as an approach to shift from the traditional design of HRM in the public sector to the finest practice in the private sector. Which, many commentators resented (Franham and Horton 1996).

Smith (1989) also noted earlier that the introduction of HRM in Australian public service has placed the traditional career service under pressure. It has caused downsizing of staff, privatization and corporatization of the public service. He further expressed that, the HRM perception has spread potentially that anyone can be redeployed or declared redundant. Which, some critics argued that, it is a symptom of wider problem, since the authorities failed to appreciate the centrality of people to the efficient and equitable operation of the APS. Moreover, the changes have caused some difficulties, which critics have expressed skepticisms. First, the function of the industrial relations was centralized in the Department of industrial relation, though there has been a significant devolution of both financial and personnel management in the APS. Despite pressure to decentralize the Department of Industrial Relations including the responsibility to handle industrial relations matters directly with unions at various enterprise levels, but to no avail (Smith 1994).

All the same, Sub-Saharan Africa countries have also faced oppositions on the introduction of HRM in their public sector managements. Especially the use of the merit system, which they cannot maintain or sustain (such an expensive system); as their economies are in bad shape. 
Moreover, the thorny issue of pay improvement was not addressed in the civil service. Because, the objective of pay reform is to justify the pay configuration by making it more transparent, impartial and efficient on the one hand. On the other hand, to increase civil servants salaries adequately so as to motivate higher performance and productivity (Mukandala \& Rwekaza 2003). And, this has been one of the main tumbling block for the Civil Service in Sierra Leone though; there is sincerity on the process of reforming the public service in order to behave like the private sector. Fleming S. (2005) mentioned below some of grave issues which needed to be addressed if, advancement is to be reached in making appropriate approaches to deliver on HRM reform in the public services:

- developing an combined approach to HRM;

- professionalizing the method to HRM;

- devolution of suitable roles to line managers;

- devolution of applicable HRM issues to vital departments.

This explicates why such countries cannot maintain reliable public services with the features of meritocracy. More unfortunately, several sub-Saharan African countries entered on reforms precisely meant to lessen surplus staff and revive the merit system. Besides, the reforms in the civil services in most SSA countries resulted in downsizing of staff instead of rightsizing their organizations. The system also caused wage erosion and compression, which subsequently led to serious decrease of skilled and professional personnel in the public services. The right to permanent and pensionable appointment for public employees was reviewed in some SSA countries with the aim of reducing the magnitude and budget of the civil services. The review led to the hire on contract substantial number of public officials (Oluwu and Ladipo 1994).

However, these reforms are made in order to weaken the labour position of public sector workers. So that, the means to hire and fire is done without much difficulties like it was in the past. This was evident in most developed and emerging economies world over. In similar vein, the introduction of HRM in the public sector in Sierra Leone has not provided the enabling environment for smooth and effective HRM related functions and practices. It has not also provided a workable criteria and strategy that will manage ethnic diversity and close the gender gap that exist in Human Resource Management Office (HRMO) in terms of recruitment processes that can help to increase women employability in the public service. Moreover, there are no laws that forbids the interference of any ruling government in the functions of the Public Service Commission and HRMO, relating to the execution of their duties. This has inhibited the quality performance of the public service in Sierra Leone (Dumbuya 2017).

Furthermore, the devolution and decentralization processes of most countries that were involved on the public services' reforms were increasing substantial, often with slight training and experienced public servants. Who may face with complex decision such as, ethical issues and accountability requirement (Smith 1989).

Finally, the approaches to public administration (traditional and the New Public Management) seem to have somewhat undesirable prejudices about public employees, apart from maybe 
those at the top management of the civil service. For instance, in the old-fashioned administration power was used to regulate the liberty and freedom of choice of employees. In the New Public Management, directors are similarly authorized occasionally at the cost of other public employees. Thus, where is the empowerment in the new public management? (Peters, 2003).

\section{Method}

My arguments in favour and against the introduction of HRM in the public sector focused on early practices in some developed and Sub-Saharan African countries. In order to carrying out the study, longitudinal study was used. This permitted me to use published works as fundamental benchmark towards achieving a concrete analysis from this paper (Saunders et al, 2016).The type of longitudinal study used is referred to as a retrospective study, which makes use of previous data that exists as comparable research was done before (Bhat n.d). Thus, the study was wholly centered on secondary data collected from several sources including related books, journals and websites.

\section{Discussion}

The introduction of HRM in the public sector is viewed with mixed feeling among commentators, as well as workers organizations. The approach has brought a reform, which has caused dilemmas and contradictions in the public service. On the one hand, the objective of the transformation is to motivate staff and promote cultural change. While on the other hand the tenure of office of public servants is weakened, followed by downsizing of staff. The downsizing of workers in the public service has led to social consequences in most developing countries. Moreover, the introduction of HRM in the public sector has increased the power of most management to determine individual employee's wages and conditions of service, instead of the institutionalized collective bargaining procedure. The reform had reduced the traditional role of trade unions in the public sector organizations. Although, certain labour unions are still active in some public sector organizations.

Another concern is, the problem of managing ethnic diversity in the public services of some SSA countries is still a challenge, which some Sub-Saharan African governments have to address. Most importantly, South Africa, Nigeria and Ethiopia have tried to solve the above issue, through affirmative action in their public services. It will be necessary if, SSA states that have not enacted the affirmative action could emulate the initiative those countries. Since, the Sub-Saharan African countries inherited ethnic diversity, thus, every ethnic group want to see its ethnic group employed in the public service. This explains why there are ethnic groups' struggles for higher positions in some SSA civil services. Because, they consider those positions as symbols of ethnic power and superiority over other ethnic groups.

Nevertheless, the introduction of HRM in the public sector has made some public organizations to compete with the private sector organizations in the provision of quality services to customers and the citizens. Since, it was the wish of people to see the public sector follow the practices of their counterpart that is; to be market oriented.

The public service reform worldwide has abridged the bulk of the civil service, to make it 
efficient and productive. Especially, in Britain, Australia and other developed countries. The size of their public services are small, but well trained, efficient and committed. For example, the next steps programme in Britain transformed the civil service from the deadweight to a sizeable and business like public service, with high performance rate. This led to staff efficiency and offering of quality services to the public. Similarly, Australian government also decentralized its public service to brand it to be more responsible and operational in the delivery of its services. In addition, the reform reinforced the public sector commitment to merit, equity and made it a career service. Unlike the above countries, some Sub-Saharan African countries still maintain their traditional structures and bureaucratic practices inherited from their colonial masters. Nevertheless, SSA countries followed the footsteps of Britain and Australia in the area of staff development, commercialization and liquidation of certain lagged and unproductive sectors of the public service, in order to maintain a sizeable and efficient public service.

The question of leadership in the SSA countries' public service is another concern. The method of recruitment and selection of leaders in most Sub-Saharan countries' civil service do not fulfill the requirement of the new human resources management practices. Some leaders do not have the required training and experience to hold certain public position, but because of nepotism, political attachment or influence, they are placed in those positions of trust. This can hinder the efficiency of the organization and deter succession planning. The public service should be politically neutral to ensure retention of highly human resources personnel. Based on this assumption, SSA countries' governments should therefore endeavor to develop future leaders. This can be achieved by developing a comprehensive programme for the development of future leaders. The establishment of an institute specialized in leadership development may be appropriate, if possible. Also, gender balance should be considered in the appointment of leaders in the public services, in order to comply with the policy of equal opportunity.

\section{Conclusion}

Overall, the introduction of HRM in the public sector is a blessing in disguise. It makes the new public service to look committed and efficient. However, the system increases poverty and crimes in most developing countries as well as transitional countries. It also reduces the adversarial role of trade unions. Besides, the issue of employee commitment instead of control in the New Public Management is just a rhetoric rather than reality. Nonetheless, the introduction of HRM in the public sector was as a desire for governments to provide increase quality public services. It was done in order to promote efficiency in the Public sector. Although, the approach incorporated the laying off of some workers; but also recruited staff with needed skills.

\section{References}

Adamolekun, L. (Ed.). (1999). Public administration in Africa: Main issues and selected country studies. Spectrum books.

Adamolekun, L., \& Kiragu K. (1999). Public Administration Reforms in Ladipo Adamolekun (ed.) Public administration in Africa. Main issues and selected countries studies, 165. USA: 
Westview press.

Alford, J. (1993). Thinking about the demise of public service boards in commonwealth and state governments. Human resource management and industrial relations in the public sector, $1-14$.

Annual, Report. (2014). Ministry of Finance and Economic Development (MoFED.) the state of public service in Sierra Leone. Accessed from Human Resource Management Office (HRMO)

Armstrong, M. (1997). A Handbook of Personnel Management Practice. London: Kogan Page.

Armstrong, M. (2009). A Handbook of Human Resource Management Practice $11^{\text {th }}$ Edition Kogan Page London and Philadelphia.

Beaumont, P. B. (1995). The Future of Employment Relations. London: SAGE Publications Ltd.

Bhat, A. (n.d). What is a Longitudinal Study? - Definition with Examples. Global VP Sales and Marketing at QuestionPro. Retrieved from

https://www.questionpro.com/blog/longitudinal-study/

Black, J., \& Upchurch, M. (1999). Public Sector Employment in G. Hollinshead, P. Nicholls and S. Tailby (eds) Employee Relations. London: Financial Times Management.

Boyne, G., Poole, M., \& Jenkins, G. (2002). Human Resource Management in the Public and Private Sectors: An Empirical Comparison.

https://doi.org/10.1111/1467-9299.00160

Boyne, G., Poole, M., \& Jenkins, G. (1999). Public Administration, 77(2), 407-420. https://doi.org/10.1111/1467-9299.00160

Brown, K. (1997). Evaluating Equity Outcomes in State Public Sectors: A Comparison of Three Housing Agencies. Australian Journal of Public Administration, 56(4), 57 - 66.

Brown, K. (2004). Human resource management in the public sector. Public Management Review. https://doi.org/10.1080/1471903042000256501

Brown, K., \& Ryan, N. (2003). Redefining Government - Community Relations through Service Agreements. Journal of Contemporary Issues in Business and Government, 9(1), 21-30.

http://citeseerx.ist.psu.edu/viewdoc/download?doi=10.1.1.425.4544\&rep=rep1\&type=pdf

Daly, J. L. (2015). Human Resource Management in the public sector Policies and Practices, Published by Routledge 2 Park Square, Milton Park, Abingdon, Oxon OX14 4RN 711 Third Avenue, New York, NY 10017, USA.

Dumbuya, A. F. (2017). A study on the effect of the introduction of appropriate human resource policies, strategies and function in the civil service: case study human resource 
management office/ministry of finance and economic development - Unpublished Master's dissertation. Accessed from IPAM-USL Library.

ECA (2010). Innovations and Best Practices in Public Sector Reforms: The Case of Civil Service in Ghana, Kenya, Nigeria and South Africa. Economic Commission for Africa. Retrieved from http://repository.uneca.org/bitstream/handle/10855/21041/Bib-19453.pdf?sequence=1

Engida, T. G., \& Bardill, J. (2013). Reforms of the public sector in the light of the new public management: A cases of Sub-Saharan Africa https://doi.org/10.5897/JPAPR11.019

Farnham, D., \& Horton, S. (1996). Managing people in the public services. London: Macmillan. https://doi.org/10.1007/978-1-349-24632-8

Fleming, S. (2005). From Personnel Management to HRM: Key Issues and Challenges. CPMR Discussion Paper 16. https://www.semanticscholar.org/paper/From-Personnel-Management-to-HRM\%3A-Key-Issu es-and-Fleming/4d168ab6d23e10160bda7cf4cf4084cb2bd957f5

Gardner, M. (1993). Introduction in M. Gardner (ed.) Human Resource Management and Industrial Relations in the Public Sector. Melbourne: Macmillan.

Gardner, M., \& Palmer, G. (1997). Employment Relations: Industrial Relations and Human Resource Management in Australia (2nd ed.), Melbourne: Macmillan.

Guest, D. (1987). Human Resource Management and Industrial Relations, Journal of Management, 24(5), 503-21. https://doi.org/10.1111/j.1467-6486.1987.tb00460.x

Gunnigle, P., \& Flood, P. (1990). Personnel Management in Ireland: Practice, Trends Developments, Dublin: Gill and Macmillan. Hawke's Second Government: Australian commonwealth Administration 1984-1987. Canberra Canberra College of Advanced Education.

Gunnigle, P., Heraty, N., \& Morley, M. (1997). Personnel and Human Resource Management Theory and Practice in Ireland, Dublin: Gill and Macmillan

Investorwords.com (n.d) Public sector definition. Retrieved from http:/www.investorwords.com/cgi-bin/getword.Cgi?3947.

Klijn, H. E. (2002). Governing Networks in the Hollow State: Contracting Out, Process Management or a Combination of the Two?. Public Management Review, 4(2), 149 - 65. https://doi.org/10.1080/14616670210130516

Lawton, A., \& Rose, A. (1994). Organisation and Management in the Public Sector, London: Pitman.

Legge, K. (1995). Human Resource Management: Rhetorics and realities. London: Macmillan. https://doi.org/10.1007/978-1-349-24156-9 
Minogue, M. (1998). Changing the State: Concepts and Practice in the Reform of the public Sector, In: Minogue M, Polidano C and Hulme D (eds). Beyond the New Public Management. Charltenham,

Mukandala, R. (ed.) (2003). African Public Administration- A reader. Electronic version, accessed at the critical importance of Public Administration to African Development http:/www.aaps.co.zw/publications/Africa.html.htm

Mutahaba, G. (2007 and 2013). (Editor) Human Resource Management in African Public Sector: Current State and Future Direction: Workshops organised by the African Public Sector Human Resource Managers' Network (APS-HRMnet) 2007 and 2013. Retrieved from http://workspace.unpan.org/sites/internet/Documents/UNPAN94251.pdf

Olowu, B. (1999). Redesigning African Civil Service Reforms, Journal of Modern African Studies, 37(1). https://doi.org/10.1017/S0022278X99002943

Olowu, D., \& Ladipo A. (1994). Human Resource Management. In Public Administration in Africa, edited by L. Adamolekum. Westview: Boulder, CO.

Peters, B.G. (2003). The Changing Nature of Public Administration: From Easy Answers to Hard Questions. issn 1648-2603 viešoji politika ir administravimas 2003. nr. 5. Retrieved from https://www.mruni.eu/upload/iblock/cfc/1_b.g.peters.pdf

Pilkington, C. (1994). The civil service in Britain today. Manchester University Press.

Premier and Cabinet (2001). The high performance public service workforce www.dpc.wa.gov.au.psmd/pubs/exec/frwork04.h

Saunders, M., Lewis, P., \& Thornhill, A. (2016). Research methods for business students. Harlow: Pearson Education.

Shim, D. (2001). Recent Human Resources Developments in OECD Member Countries. Public Personnel Management, $\quad 30(3), \quad 323 \quad-\quad 47$. https://doi.org/10.1177/009102600103000304

Smith, C. S. (1994). A new Career service?. In M. Gardner ed. Human Resource Management and Industrial Relations in the Public sector. Australia: Education Australia PTY Ltd.

Smith, R. F. I (1989). Directions in Public Sector Personnel Policies- An overview". In D.C. Corbett, C Selby Smith and R.F.I Smith (eds.). Public Sector Personnel Policies for the 1990's. Melbourne: Public Sector Management Institute, Monash University.

South Africa "White Paper" (1995) Retrieved from:

www.dpsa.gov.za/dpsa2g/documents/acts\&regulations/.../white.../pservicedec.pdf

Stewart, J., \& Walsh K. (1992). Change in the Management of Public Services, Public Administration 70,499-518. Accessed from https://doi.org/10.1111/j.1467-9299.1992.tb00952.x

Storey, J. (1989). Human Resource Management in the Public Sector Public Money and 


\section{Macrothink \\ International Journal of Human Resource Studies \\ ISSN 2162-3058 2019, Vol. 9, No. 4}

Management, 9(3), 19-24. https://doi.org/10.1080/09540968909387552

Storey, J. (1995). Human Resource Management: A Critical Text, London: Routledge.

United Nations (2005). Human Resources for effective public administration in a globalized world.

ST/ESA/PAD/SER.E/65.

https://publicadministration.un.org/publications/content/PDFs/E-Library\%20Archives/2005\%

20Human $\% 20$ Resources $\% 20$ for $\% 20$ Effective $\% 20$ Public $\% 20$ Administration $\% 20 \mathrm{in} \% 20 \mathrm{a} \% 20$

Globalized\%20World.pdf

\section{Copyright Disclaimer}

Copyright for this article is retained by the author(s), with first publication rights granted to the journal.

This is an open-access article distributed under the terms and conditions of the Creative Commons Attribution license (http://creativecommons.org/licenses/by/4.0/). 